Praca poglądowa/Review

\title{
Zalecenia dotyczące oceny schorzeń współistniejących u chorych na przewlekłą białaczkę szpikową w procesie wyboru inhibitora kinaz tyrozynowych
}

\section{Recommendations for assessment of co-morbidities and tyrosine kinase inhibitor choice in patients suffering from chronic myeloid leukemia}

\author{
Tomasz Sacha $^{1, *}$, Sebastian Szmit ${ }^{2}$, Dorota Zozulińska-Ziółkiewicz ${ }^{3}$, \\ Witold Prejzner ${ }^{4}$, Joanna Góra-Tybor ${ }^{5}$ \\ ${ }^{1}$ Katedra Hematologii Collegium Medicum Uniwersytetu Jagiellońskiego, Kraków, Polska \\ ${ }^{2}$ Klinika Krq̨żenia Płucnego i Chorób Zakrzepowo-Zatorowych, Centrum Medyczne Kształcenia Podyplomowego, \\ Europejskie Centrum Zdrowia, Otwock, Polska \\ ${ }^{3}$ Katedra i Klinika Chorób Wewnętrznych i Diabetologii, Uniwersytet Medyczny w Poznaniu, Szpital im. Fr. Raszei, \\ Poznań, Polska \\ ${ }^{4}$ Klinika Hematologii i Transpantologii Gdańskiego Uniwersytetu Medycznego, Gdańsk, Polska \\ ${ }^{5}$ Instytut Hematologii i Transfuzjologii $w$ Warszawie, Polska
}

IN F ORMACJE O ARTYKULE

Historia artykułu:

Otrzymano: 10.05.2016

Zaakceptowano: 24.06.2016

Dostępne online: 03.07.2016

Słowa kluczowe:

- przewlekła białaczka szpikowa

- inhibitory kinazy tyrozynowej

- choroby współistniejące

Keywords:

- Chronic myeloid leukemia

- Tyrosine kinase inhibitors

- Co-morbidities

\begin{abstract}
A B S T R A C T
Treatment of chronic myeloid leukemia with tyrosine kinase inhibitors (TKI) is very effective. The vast majority of patients achieve deep and long-lasting therapeutic responses including those on molecular level. Understanding the adverse effects of TKIs is of great importance during life-long therapy. The safety profile of TKI should be considered especially when used in patients suffering from various co-morbidities. In this paper, treatment recommendations for patients suffering from diabetes mellitus, atherosclerosis with circulation disturbances in peripheral arteries, congestive heart failure, pulmonary hypertension and pleural effusions are presented. Drug interactions between TKIs and medicaments used in the treatment of the above-mentioned co-morbidities are discussed.
\end{abstract}

(c) 2016 Polskie Towarzystwo Hematologów i Transfuzjologów, Instytut Hematologii i Transfuzjologii. Published by Elsevier Sp. z o.o. All rights reserved.

\footnotetext{
* Adres do korespondencji: Katedra Hematologii Collegium Medicum Uniwersytetu Jagiellońskiego, ul. Kopernika 17, 31-501 Kraków, Polska. Tel.: +48 1242476 89; fax: +48 124247426 .

Adresy email: sachatom@gmail.com, sachat@interia.pl (T. Sacha).

http://dx.doi.org/10.1016/j.achaem.2016.06.001

0001-5814/@ 2016 Polskie Towarzystwo Hematologów i Transfuzjologów, Instytut Hematologii i Transfuzjologii. Published by Elsevier Sp. $\mathrm{z}$ o.o. All rights reserved.
} 


\section{Wstęp}

Od chwili zarejestrowania imatynibu w Polsce minęło już 15 lat, inhibitory kinaz tyrozynowych 2 generacji (2GIKT) są dostępne od ok. 10. Na przestrzeni tego czasu w miarę nabywania doświadczenia w leczeniu przewlekłej białaczki szpikowej doszło do istotnej ewolucji podejścia do terapii tej choroby. U znakomitej większości chorych możliwe jest uzyskanie dobrej kontroli nad jej przebiegiem i doprowadzenie do osiągnięcia głębokich odpowiedzi na leczenie, nawet na poziomie molekularnym. Pojawiające się jednak nowe działania niepożądane inhibitorów kinaz tyrozynowych wymuszają bardziej holistyczne, a jednocześnie bardziej indywidualne potraktowanie pacjenta, poza białaczką obciążonego niejednokrotnie innymi schorzeniami, które należy brać pod uwagę przy dokonywaniu optymalnego wyboru terapii. Niniejsza praca zrodziła się z potrzeby sformułowania zaleceń dotyczących postępowania diagnostyczno-terapeutycznego w sytuacjach wystąpienia istotnych klinicznie działań niepożądanych związanych z rutynowo stosowanymi IKT i występujących najczęściej u chorych $\mathrm{z}$ rozpoznanymi innymi schorzeniami istotnymi dla rokowania. Artykuł omawia zagadnienia związane z zaburzeniami gospodarki węglowodanowej i metabolizmu lipidów, powikłania wynikające ze współwystępowania chorób kardiologicznych, takich jak obwodowa miażdżyca, zastoinowa niewydolność krążenia czy nadciśnienie płucne, problematykę pojawiających się wysięków opłucnowych w aspekcie stosowania IKT, a także możliwe interakcje pomiędzy IKT a lekami stosowanymi $\mathrm{z}$ powodu wspomnianych stanów klinicznych.

\section{Zaburzenia metaboliczne}

\section{Zaburzenia metabolizmu glukozy}

Cukrzyca definiowana jest przez hiperglikemię wynikającą z defektu wydzielania i/lub działania insuliny [1]. Prognozuje się, że cukrzyca określana mianem epidemii stanie się w najbliższych 10 latach jednym z największych problemów zdrowotnych, a aktualna liczba około $380 \mathrm{mln}$ chorych na świecie wzrośnie do prawie $600 \mathrm{mln} \mathrm{w}$ ciągu 10-15 lat [2]. W Polsce brak jest rejestru osób z cukrzycą. Szacowane dane dotyczące zaburzeń metabolizmu w Polsce wskazują liczbę około $3 \mathrm{mln}$ chorych na cukrzycę, prawie $2 \mathrm{mln}$ osób ze stanem przedcukrzycowym. Prawdopodobnie u około $1 \mathrm{mln}$ mieszkańców Polski choroba nadal pozostaje nierozpoznana [3]. Rozpoznanie zaburzeń metabolizmu glukozy na etapie stanu przedcukrzycowego zwiększa szansę na skuteczność działań pozwalających spowolnić lub nie dopuścić do rozwoju cukrzycy. Dotyczy to w szczególności osób zagrożonych cukrzycą typu 2. Zasady rozpoznawania zaburzeń metabolizmu glukozy przedstawiono w tabeli I. Do grup zwiększonego ryzyka zachorowania na cukrzycę należą: osoby po 45. roku życia i niezależnie od wieku osoby $\mathrm{z}$ nadwagą lub otyłością (BMI $\geq 25 \mathrm{~kg} / \mathrm{m}^{2}$ ), szczególnie brzuszną (obwód talii $\geq 80 \mathrm{~cm}$ u kobiet $\mathrm{i} \geq 94 \mathrm{~cm}$ u mężczyzn); osoby mało aktywne fizycznie (<150 minut tygodniowo); osoby mające we wcześniejszych badaniach laboratoryjnych stwierdzoną hiperglikemię; osoby z chorobą układu krążenia; osoby z dyslipidemią (szczególnie gdy stężenie frakcji HDL cholesterolu $<40 \mathrm{mg} / \mathrm{dl}$ [1 mmol/l] i/lub triglicerydów >150 mg/dl [1,7 mmol/l]); osoby z nadciśnieniem tętniczym; kobiety z zespołem policystycznych jajników; kobiety z przebytą cukrzycą ciążową; kobiety, które urodziły dziecko $>4 \mathrm{~kg}$; osoby z cukrzycą występującą w rodzinie; osoby w stanach generujących insulinooporność m.in. przewlekle leczone sterydami, analogami somatostatyny i innymi lekami o działaniu diabetogennym [2]. Wzmożoną czujność glikemiczną należy mieć przy stosowaniu inhibitorów kinaz tyrozynowych (IKT). Wśród nich są takie (nilotynib), które zwiększają ryzyko ujawnienia zaburzeń metabolizmu glukozy lub przyczyniają się do pogorszenia kontroli metabolicznej wcześniej rozpoznanej cukrzycy [4].

Kryteria wyrównania metabolicznego cukrzycy obejmują [2]: wartość glikowanej hemoglobiny (HbA1c) nie wyższa niż 7\% (53 mmol/mol), z uwzględnieniem celów szczegółowych, tj. dla cukrzycy typu 1 przy braku zwiększonego ryzyka hipoglikemii i negatywnego wpływu na komfort życia oraz krótkotrwałej cukrzycy typu 2 (HbA1c $\leq 6,5 \%$ [48 mmol/ mol]), dla kobiet planujących i będących w ciąży (HbA1c $\leq 6 \%$ [42 mmol/mol]), dla chorych $\mathrm{w}$ wieku $\geq 70$. roku życia i/lub cukrzycą z powikłaniami makroangiopatycznymi (przebyty zawał serca i/lub udar mózgu) i/lub licznymi chorobami towarzyszącymi (HbA1c $\leq 8 \%$ [64 $\mathrm{mmol} / \mathrm{mol}]$ ). Nadmienić należy, że jeżeli u chorych po 65. roku życia przewidywane jest przeżycie dłuższe niż 10 lat, należy dążyć do osiągnięcia celu HbA1c $\leq 7 \%$. Przy HbA1c $\leq 7 \%$ wartości glikemii $\mathrm{w}$ prowadzonej przez pacjenta samokontroli $\mathrm{z}$ reguły nie przekraczają progu nerkowego, tj. $180 \mathrm{mg} / \mathrm{dl}$ (10 mmol/l). Kryteria wyrównania lipidowego obejmują stężenie

Tabela I - Zasady rozpoznawania zaburzeń metabolizmu glukozy wg Polskiego Towarzystwa Diabetologicznego [2] Table I - The principles of recognizing glucose metabolism disorders according to Polish Diabetes Association [2]

Stężenie glukozy w osoczu krwi żylnej pobranej o dowolnej porze, niezależnie od czasu spożytego posiłku

$\geq 200 \mathrm{mg} / \mathrm{dl}(11 ., 1 \mathrm{mmol} / \mathrm{l})$ przy objawach hiperglikemii, tj. wzmożone pragnienie, wielomocz, chudnięcie - CUKRZYCA

\author{
Stężenie glukozy w osoczu krwi żylnej \\ na czczo (8-11 godzin od ostatniego posiłku) \\ 70-99 mg/dl (3,9-5,5 mmol/l) - normoglikemia \\ 100-125 mg/dl (5,6-6,9 mmol/l) - nieprawidłowa \\ glikemia na czczo \\ $\geq 126 \mathrm{mg} / \mathrm{dl}$ (7.,0 mmol/l), jeżeli 2-kotnie - \\ CUKRZYCA
}

Stężenie glukozy w osoczu krwi żylnej $\mathrm{w} 120$. minucie doustnego testu tolerancji glukozy (OGTT)

$<140 \mathrm{mg} / \mathrm{dl}$ (7,8 mmol/l) - prawidłowa tolerancja glukozy

140-199 mg/dl (7,8-11 mmol/l) nieprawidłowa tolerancja glukozy (IGT) $\geq 200 \mathrm{mg} / \mathrm{dl}(11,1 \mathrm{mmol} / \mathrm{l})$ - CUKRZYCA 
Tabela II - Konsensus definicji zespolu metabolicznego według IDF (International Diabetes Federation) oraz AHA/NHLBI (American Heart Association/ National Heart, Lung and Blood Institiute) [5]

Table II - Consensus on the metabolic syndrome definition according to IDF (International Diabetes Federation) and AHA/NHLBI (American Heart Association/ National Heart, Lung and Blood Institute) [5]

Obecność co najmniej 3 z wymienionych czynników

\begin{tabular}{ll}
\hline \multicolumn{1}{c}{ Czynnik } & \multicolumn{1}{c}{ Wartość } \\
\hline Obwód talii (zależny od grupy populacyjnej) & Europejczycy; kobiety $\geq 80 \mathrm{~cm}, \mathrm{mężczyźni} \geq 94 \mathrm{~cm}$ \\
& Amerykanie: kobiety $\geq 88 \mathrm{~cm}, \mathrm{mężczyźni} \geq 102 \mathrm{~cm}$ \\
Stężenie trójglicerydów & Azjaci: kobiety $\geq 80 \mathrm{~cm}, \mathrm{mężczyźni} \geq 90 \mathrm{~cm}$ \\
Stężenie frakcji HDL-cholesterolu & $\geq 150 \mathrm{mg} / \mathrm{dl}$ lub stosowane leczenie hipolipemizujące \\
Ciśnienie tętnicze krwi & $<40 \mathrm{mg} / \mathrm{dl}$ (mężczyźni), $<50 \mathrm{mg} / \mathrm{dl}(\mathrm{kobiety})$ \\
Stężenie glukozy w osoczu krwi na czczo & $\geq 130 / 85 \mathrm{mmHg}$ lub stosowane leczenie hipotensyjne \\
\hline
\end{tabular}

w surowicy cholesterolu całkowitego $<175 \mathrm{mg} / \mathrm{dl}(4,5 \mathrm{mmol} / \mathrm{l})$; frakcji LDL-cholesterolu $<70 \mathrm{mg} / \mathrm{dl}$ (1,9 mmol/l) u chorych na cukrzycę i chorobę niedokrwienną serca i niezależnie od niej w wieku $\geq 40$ lat. Dopuszczalna jest wartość LDL-cholesterolu <100 mg/dl (2,6 mmol/l) u osób z cukrzycą typu $1<40$ roku życia; frakcji HDL-cholesterolu $>40 \mathrm{mg} / \mathrm{dl}$ (1 mmol/l) u mężczyzn i >50 mg/dl (1,3 mmol/l) u kobiet; triglicerydów $<150 \mathrm{mg} / \mathrm{dl}(1,7 \mathrm{mmol} / \mathrm{l})$. Kryterium wyrównania ciśnienia tętniczego $\mathrm{u}$ osób $\mathrm{z}$ cukrzycą to ciśnienie tętnicze skurczowe $<140 \mathrm{mmHg}$ i rozkurczowe $<90 \mathrm{mmHg}$. Duży niepokój budzi fakt, że mniej niż 10\% chorych na cukrzycę osiąga złożony cel terapeutyczny [3]. Stosowanie leków o działaniu diabetogennym zwiększa ryzyko ujawnienia cukrzycy, szczególnie przy konstelacji niekorzystnych czynników metabolicznych definiowanych jako zespół metaboliczny. Konsensus definicji Zespołu Metabolicznego przedstawiono w tabeli II [5]. Współwystępowanie czynników definiujących zespół metaboliczny stanowi zwiększone ryzyko chorób krążenia oraz cukrzycy typu 2.

Otyłość brzuszna ściśle związana ze zjawiskiem zmniejszonej wrażliwości tkanek na działanie insuliny (insulinooporność) współistnieje najczęściej z aterogenną dyslipidemią (hipertriglicerydemia $\mathrm{z}$ obniżonym stężeniem cholesterlu frakcji HDL) i nadciśnieniem tętniczym. Na tym etapie nawet przy stwierdzanej normoglikemii istnieją zaburzenia metabolizmu glukozy wynikające $\mathrm{z}$ nadmiernej sekrecji insuliny (hiperinsulinemia) pogłębiającej patologię związaną z insulinoopornością. Opisane zjawiska leżą także u podłoża niealkoholowej stłuszczeniowej choroby wątroby, która może prowadzić do zapalenia i w dalszej konsekwencji włóknienia i przebudowy marskiej. Ryzyko metaboliczne jest ściśle związane ze zwiększonym ryzykiem zdarzeń krążeniowych. Do tzw. klasycznych czynników ryzyka chorób o podłożu miażdżycowym należą: nadciśnienie tętnicze, wysokie stężenie frakcji LDL-cholesterolu, niskie stężenie frakcji HDL-cholesterolu, palenie tytoniu oraz hiperglikemia. W przypadku stwierdzenia stanu przedcukrzycowego u osoby z nadwagą lub otyłością zalecana jest zmiana stylu życia, która prowadzić ma do redukcji masy ciała. Zachowania behawioralne powinny ukierunkowane być nie tylko na zdrowe żywienie, ale, zgodnie $\mathrm{z}$ aktualną piramidą zdrowego życia, aktywność fizyczną [6]. Leczenie metaboliczne preferuje ćwiczenia tlenowe o umiarkowanej intensywności, najlepiej codziennie, nie mniej niż 30 minut. Przy braku przeciwwskazań do metforminy należy rozważyć ten rodzaj farmakoterapii już na tym etapie zaburzeń metabolizmu glukozy. Corocznie powinny być prowadzone badania w kierunku cukrzycy zgodnie z wytycznymi dla diagnostyki zaburzeń metabolizmu glukozy. Pacjent $\mathrm{z}$ rozpoznaną cukrzycą, w zależności od typu choroby oraz sposobu leczenia przeciwhiperglikemicznego, pozostaje pod opieką diabetologa lub w opiece łączonej lekarza Podstawowej Opieki Zdrowotnej i diabetologa. Obecność przewlekłych powikłań cukrzycy czyni pacjenta multidyscyplinarnym, pozostającym pod opieką wielu specjalistów m.in. okulisty, nefrologa, neurologa, kardiologa. Ocena wskaźników kontroli metabolicznej, w tym HbA1c i lipidogramu zalecana jest raz w roku, u pacjentów ze stabilnym przebiegiem choroby, osiągających cele leczenia. U chorych nieosiągających celów leczenia oraz u tych, u których dokonano zmiany sposobu leczenia, zalecana jest kontrola HbA1c co najmniej raz na kwartał [7]. Przy wyborze IKT u pacjenta z PBSz należy określić ryzyko metaboliczne i zalecać te leki, o których wiadomo, że nie wywierają negatywnego wpływu na metabolizm glukozy i lipidów.

\section{Choroba okluzyjna tętnic obwodowych w przebiegu leczenia PBSz}

Choroba okluzyjna tętnic obwodowych (PAOD; peripheral artery occlusive disease) dotyczy zmian $\mathrm{w}$ tętnicach $\mathrm{z}$ wyłączeniem tętnic wieńcowych, centralnego układu nerwowego (CUN) i łuku aorty. Przyczyną zmian w tętnicach (najczęściej dotyczy naczyń kończyn dolnych) w ponad 95\% jest miażdżyca tętnic obwodowych. W pozostałych przypadkach zmiany mogą być wynikiem zakrzepowo-zarostowego zapalenia tętnic (choroba Buergera), ucisku przez torbiel podkolanową, tętniaka tętnicy podkolanowej, przebytego urazu mechanicznego tętnicy, zatorów obwodowych. Do głównych czynników ryzyka PAOD zalicza się palenie tytoniu, cukrzycę, nadciśnienie tętnicze, hipercholesterolemię, płeć męską i wiek (ryzyko wzrasta z wiekiem). Wobec dużej rezerwy czynnościowej przepływu krwi w tętnicach, objawy PAOD pojawiają się późno - zwykle, gdy zwężenie wynosi ponad 50\% światła naczynia. Do głównych objawów PAOD należą chromanie przestankowe (ból zlokalizowany jest w miejscu poniżej zwężenia - najczęściej w podudziu, ustępujący po krótkim odpoczynku), łatwa męczliwość kończyn, zwiększona wrażliwość na zimno, parestezje. W zaawansowanej postaci PAOD 
występuje ból spoczynkowy, a także dochodzić może do powstania zmian troficznych lub martwicy skóry. W badaniu fizykalnym stwierdza się w początkowym etapie bladość skóry kończyn, zblednięcie stóp występujące po uniesieniu kończyny dolnej, a w postaciach bardziej zaawansowanych zmiany troficzne na kończynach dolnych pod postacią przebarwień, utraty owłosienia, zaników mięśniowych, owrzodzeń, martwicy i niewyczuwalnego tętna na tętnicach kończyn dolnych [8]. Tętno oceniane powinno być na tętnicy grzbietowej stopy, piszczelowej tylnej, podkolanowej i udowej. Niewykrycie tętna pozwala w przybliżeniu na określenie miejsca lokalizacji niedrożności. Do przesiewowej oceny wystąpienia PAOD służy określenie wskaźnik kostka-ramię (ABI; Ankle Brachial Index) [9]. Badanie to jest proste do wykonania, jednakże do jego prawidłowego wykonania konieczne jest posiadanie sondy ultrasonograficznej (w celu dokładnej oceny ciśnienia skurczowego na kończynach). Określenie wskaźnika wykonuje się poprzez zmierzenie ciśnienia skurczowego na kończynie górnej i dolnej, a wskaźnik jest ilorazem ciśnienia skurczowego na kończynie dolnej i ciśnienia skurczowego na kończynie górnej. Wskaźnik pomiędzy 0,9-0,7 świadczy o obecności zwężenia, a poniżej 0,6 odpowiada krytycznemu zwężeniu. Badaniem, które potwierdza podejrzenie PAOD, jest badanie ultrasonograficzne naczyń tętniczych. Decyzję o zabiegu chirurgicznym naczyń tętniczych podejmuje się zazwyczaj po wykonaniu dokładniejszych badań, takich jak angio-TK, angio-MRI czy cyfrowa angiografia subtrakcyjna. Do nowszych nieinwazyjnych metod oceny przepływu w naczyniach tętniczych należy tonometria aplanacyjna (PWV; Pulse Wave Velocity) - ocena możliwości zastosowania tej metody w POAD jest w trakcie badań. Klasyfikacja stopnia zaawansowania PAOD wg Fontaine'a wyróżnia 4 okresy w zależności od objawów klinicznych (Tab. III) [10]. Na konsultacje do chirurga naczyniowego (w celu kwalifikacji do rodzaju postępowania: zachowawcze czy chirurgiczne) należy kierować chorych z rozpoznaniem POAD, wysuwanym na podstawie wywiadu i badania fizykalnego, najlepiej uzupełnionego o badanie wskaźnika kostkaramię i USG tętnic. W ostatnich latach zwrócono uwagę na zwiększone występowanie PAOD w grupie chorych leczonych nilotynibem i ponatynibem. Badania przeprowadzone przez Kim i wsp. [11] wykazały, że chorzy leczeni w pierwszej linii nilotynibem są narażeni na wystąpienie PAOD 10-krotnie częściej niż leczeni imatynibem. W badaniu Gilesa i wsp. [12]

Tabela III - Klasyfikacja choroby okluzyjnej naczyń obwodowych wg Fontaine'a [10]

Table III - Fontaine classification of peripheral artery disease [10]

\begin{tabular}{ll}
$\begin{array}{l}\text { Okres zaawansowania Wg } \\
\text { Fontaine'a }\end{array}$ & \multicolumn{1}{c}{ Objawy } \\
\hline I & bezobjawowy \\
IIa & Chromanie $<200 \mathrm{~m}$ \\
IIb & Chromanie $>200 \mathrm{~m}$ \\
III & Ból spoczynkowy \\
IV & Martwica i owrzodzenia \\
& niedokrwienne \\
\hline
\end{tabular}

odsetek POAD w grupie leczonych nilotynibem wyniósł 1,25\%, podczas gdy w grupie leczonych imatynibem 0,15\%. Częstość występowania PAOD w grupie leczonych dazatynibem jest niewielka i podobna do częstości tego powikłania u chorych leczonych imatynibem [13]. W badaniu ENESTnd po 60 miesiącach częstość PAOD w grupie leczonych nilotynibem w dawce $600 \mathrm{mg}$ dziennie wyniosła 2,5\%, natomiast w badaniu DASISION w tym samym okresie w grupie leczonych dazatynibem $100 \mathrm{mg} / \mathrm{d}$ nie obserwowano zdarzeń o charakterze PAOD [13]. Znacznie zwiększoną częstość występowania PAOD obserwowano w grupie chorych leczonych ponatynibem, w badaniu PACE wyniosła ona 4,9\% [14]. Dotychczasowe dane kliniczne wskazują, że terapia bosutynibem nie wiąże się ze wzrostem częstości PAOD [15]. Przyczyny zwiększonej częstości POAD w grupie leczonych nilotynibem upatruje się w jego potencjalnym działaniu proaterogenym i antyangiogennym (poprzez m.in. wpływ na kinazę KIT), jak również poprzez swój niekorzystny efekt metaboliczny polegający na zwiększaniu poziomu cholesterolu i glukozy w surowicy. Podobny patomechanizm przypisuje się ponatynibowi [16]. Podejście terapeutyczne do PAOD u chorych z przewlekłą białaczką szpikową leczonych nilotynibem lub ponatynibem uzależnione jest od okresu zaawansowania PAOD. W I lub II stopniu zaleca się kontynuację dotychczasowym inhibitorem kinazy tyrozynowej, eliminację czynników ryzyka PAOD, ścisłą obserwację chorego: wykonywanie badań (wskaźnik ABI co 3-6 m-cy, a gdy wskaźnik spada poniżej $<0,9$, badanie USG tętnic), lipidogram, stężenie glukozy co $6 \mathrm{~m}$-cy i rozważenie profilaktycznego zastosowania leków przeciwpłytkowych (kwas acetylosalicylowy $75 \mathrm{mg} / \mathrm{d}$ lub clopidogrel $75 \mathrm{mg} / \mathrm{d}$ ).W okresie III lub IV wg Fontaine'a - chorzy przy braku przeciwwskazań zazwyczaj poddawani są zabiegom rewaskularyzacyjnym. W każdym przypadku terapii nilotynibem i wystąpienia PAOD w okresie III i IV wg Fontaine'a należy dążyć do zmiany terapii (o ile to jest możliwe) na inny inhibitor kinazy tyrozynowej o mniejszym negatywnym wpływie na PAOD. U wszystkich chorych należy zastosować leczenie przeciwpłytkowe i eliminować czynniki ryzyka PAOD. Trzeba pamiętać, że ryzyko wystąpienia PAOD u chorych leczonych nilotynibem i ponatynibem jest znamiennie wyższe niż chorych leczonych imatynibem i dazatynibem. Chorzy leczeni nilotynibem i ponatynibem wymagają szczególnie dokładnego monitorowania w kierunku wystąpienia PAOD, dotyczy to zwłaszcza chorych z czynnikami ryzyka PAOD. Trzeba pamiętać, że PAOD w grupie leczonych nilotynibem jest rozpoznawany po około 2-2,5 roku od rozpoczęcia leczenia. U chorych z przewlekłą białaczką szpikową i rozpoznaną PAOD nie zaleca się stosowania nilotynibu i ponatynibu.

\section{Zastoinowa niewydolność krążenia i nadciśnienie płucne a wybór optymalnego IKT}

Występowanie powikłań krążeniowych podczas leczenia PBSz wydaje się być wypadkową swoistego działania molekularnego IKT oraz indywidualnej predyspozycji pacjenta wynikającej ze schorzeń współistniejących. Niewydolność serca i nadciśnienie płucne są powikłaniami, które mogą bezpośrednio zagrażać życiu pacjenta, a przynajmniej 
istotnie wpłynąć na pogorszenie jego jakości. Kluczowe $\mathrm{w}$ przewidywaniu wystąpienia tych powikłań u chorych na PBSz jest identyfikowanie typowych czynników ryzyka. Podczas kwalifikacji do leczenia IKT każdy pacjent powinien mieć ocenioną wyjściowo ogólną wydolność fizyczną, której podstawowym elementem jest ocena tolerancji wysiłku oraz wydolności serca, a także tzw. klasyczne czynniki ryzyka dla wystąpienia niewydolności serca i nadciśnienia płucnego.

Podczas leczenia PBSz inhibitorami kinaz tyrozynowych wszystkie współistniejące choroby układu krążenia i ich czynniki ryzyka powinny być odpowiednio kontrolowane. Powyższe postępowanie w Polsce powinno być prowadzone $\mathrm{w}$ oparciu o rekomendacje Europejskiego Towarzystwa Kardiologicznego (European Society of Cardiology) dotyczące diagnostyki i leczenia niewydolności serca [17] oraz odpowiednio dotyczące diagnostyki i leczenia nadciśnienia płucnego [18].

\section{Inhibitory kinaz tyrozynowych jako czynniki ryzyka niewydolności serca i nadciśnienia płucnego}

Uznaje się, że imatynib, dazatinib i nilotynib mogą być przyczyną rozwoju niewydolności serca [19]. Udokumentowano również, że jeśli wystąpi ostra niewydolność serca podczas terapii imatynibem, to jest ona odwracalna, dzięki leczeniu kardiologicznemu można uzyskać pełną normalizację funkcji skurczowej serca, ale podczas kolejnych linii leczenia IKT, tj. dazatynibem lub nilotynibem, może dojść do nawrotu niewydolności serca [20]. Imatyinib może być przyczyną wystąpienia niewydolności serca zwłaszcza u osób ze współistniejącymi czynnikami ryzyka miażdżycy [21]. Dostępne dane wskazują, że zastoinowa niewydolność serca podczas terapii imatynibem może dotyczyć około 0,51,1\% [22], szczególnie osób starszych z chorobami współistniejącymi. Największa praca analizująca ryzyko niewydolności serca związane $\mathrm{z}$ imatynibem podkreśla, że spośród obserwowanych 1276 chorych skurczowej niewydolności serca doświadczyły 22 osoby (1,7\%), we wszystkich przypadkach uznano, że imatynib mógł być prawdopodobną przyczyną [23]. Mediana wieku była wysoka: 70 lat (zakres 4983). Ponadto u 6 chorych (27\%) była już rozpoznana niewydolność serca, a także identyfikowano inne istotne czynniki predysponujące do rozwoju niewydolności serca: cukrzyca u 6 (27\%)chorych, nadciśnienie tętnicze u 10 [45\%], choroba wieńcowa u 8 (36\%), zaburzenia rytmu u 3 (14\%), kardiomiopatia u 1 (5\%). W przypadku dazatynibu częstość pojawiania się niewydolności serca ocenia się w granicach 2-4\% [24]. W przypadku tego leku pojawia się konieczność rozróżniania lewokomorowej od prawokomorowej niewydolności serca. W ostatnim czasie ukazały się prace dokumentujące zupełnie nowe powikłanie krążeniowe u chorych leczonych dazatynibem $[25,26]$, tj. tętnicze nadciśnienie płucne (PAH; pulmonary arterial hypertension). W badaniu DASISION [27] gdzie dazatynib był stosowany w dawce $100 \mathrm{mg}$, objawy PAH rozpoznano u 3 chorych, czyli 1,2\%. W rejestrze francuskim [28], w okresie od listopada 2006 roku do września 2010 roku, opisano 9 przypadków PAH. Obserwacje szybko ukazały, że w odróżnieniu od innych postaci nadciśnienia płucnego w tym przypadku objawem przepowiadającym wydają się być wysięk opłucnowy i wysięk osierdziowy [29]. Zatem ich wystąpienie powinno być kolejną przesłanką do poszerzania diagnostyki. W przypadku nilotynibu pojawia się inny problem kliniczny. W jednej z najnowszych prac udowodniono, że co prawda nilotynib nie wpływa na obniżenie funkcji skurczowej lewej komory serca, ale odnotowano nowe przypadki bezobjawowej dysfunkcji rozkurczowej lewej komory serca [30]. Ta postać dysfunkcji serca może również wiązać się ze wzrostem ciśnienia w tętnicy płucnej. Powyższe obserwacje skłaniają do zalecenia, aby u chorych leczonych inhibitorami kinaz tyrozynowych dokonywać kontroli funkcji skurczowej prawej i lewej komory wraz z oceną funkcji rozkurczowej lewej komory serca. U każdego pacjenta $z$ wywiadem rozpoznanej choroby układu krążenia przed rozpoczęciem leczenia IKT należy wykonać badanie EKG i badanie echokardiograficzne serca. W przypadku nieprawidłowości w tych badaniach należy również dokonać pomiaru stężenia NTproBNP/BNP. Podobną diagnostykę należy rozważyć u każdego chorego, u którego możemy podejrzewać chorobę serca na podstawie zgłaszanych objawów. Badania powyższe należy powtarzać podczas leczenia IKT, jeśli pojawią się objawy sugerujace kardiotoksyczność, tj. pojawi się duszność wysiłkowa (lub spoczynkowa), nasili się nietolerancja wysiłku, pojawią się obrzęki kończyn dolnych, trzeszczenia nad polami płucnymi lub płyn w jamach opłucnowych [31].

\section{Czynniki ryzyka dla niewydolności serca}

Eksperci Amerykańskiego Towarzystwa Kardiologicznego zalecają, aby rozpoznawać tzw. stadium A niewydolności serca [32]. Dotyczy to grupy chorych, którzy mają prawidłowy obraz echokardiograficzny morfologii i funkcji serca, ale występują u nich istotne czynniki ryzyka dla rozwoju niewydolności serca. Do klasycznych czynników ryzyka należy choroba wieńcowa, nadciśnienie tętnicze, cukrzyca, otyłość, starszy wiek, hipercholesterolemia oraz stosowanie substancji potencjalnie toksycznych dla serca (m.in. leki przeciwnowotworowe). Według tej klasyfikacji, wszystkie bezobjawowe nieprawidłowości funkcji i geometrii serca stanowią już stadium B niewydolności serca, a gdy wystąpią typowe objawy kliniczne (duszność wysiłkowa, męczliwość itd.), należy rozpoznać stadium C niewydolności serca. Klasyfikacja ta jest bardzo praktyczna w sensie rozumienia prewencji względem postępującej choroby mięśnia sercowego. Właściwe rozpoznanie niewydolności serca może sprawiać trudności. Eksperci Europejskiego Towarzystwa Kardiologicznego dla uproszczenia niewydolność serca definiują klinicznie jako zespół, w którym u chorego występują typowe objawy podmiotowe (np. duszność, obrzęki wokół kostek i zmęczenie) oraz przedmiotowe (np. podwyższone ciśnienie w żyłach szyjnych, trzeszczenia nad polami płucnymi oraz przemieszczenie uderzenia koniuszkowego) wynikające z nieprawidłowości budowy i czynności serca. Objawy niewydolności serca wynikają z zatrzymania w organizmie nadmiaru sodu i wody, a powodem jest niedostateczna praca serca jako pompy. Dlatego 
w nazewnictwie amerykańskim pozostaje w użyciu termin „zastoinowej niewydolności serca”. Ryzyko nadmiernej retencji płynów i kardiotoksyczności podczas stosowania IKT w PBSz powinno skłaniać do wnikliwego kardiologicznego monitoringu chorych, zwłaszcza tych z istotnymi czynnikami ryzyka niewydolności serca [33]. W postępującej niewydolności serca optymalizacja stanu nawodnienia ma kluczowe znaczenie [34, 35]. U pacjentów ze zmniejszoną kurczliwością serca i zmniejszonym opróżnianiem lewej komory rozpoznaje się tzn. dysfunkcję skurczową. Główną przyczyną skurczowej niewydolności serca jest choroba wieńcowa (2/3 przypadków), czynnikami sprzyjającymi są również cukrzyca i nadciśnienie tętnicze - silne czynniki ryzyka miażdżycy. Wśród innych przyczyn wymienia się zapalenie mięśnia sercowego oraz toksyny. Rozpoznanie niewydolności serca $\mathrm{u}$ pozostałych chorych $\mathrm{z}$ zachowaną funkcją skurczową lewej komory (frakcja wyrzutowa lewej komory zazwyczaj powyżej 50\%) stwarza wiele problemów. Zawsze w takim wypadku wymagane jest wykluczenie innych przyczyn męczliwości, np. niedokrwistości czy choroby płuc [36, 37]. Zazwyczaj nie stwierdza się powiększenia jam serca, raczej występuje zwiększona grubość ściany lewej komory oraz powiększony rozmiar lewego przedsionka, u większości obserwuje się zaburzenia czynności rozkurczowej w echokardiografii. Częściej dotyczy to osób starszych, kobiet i osób otyłych. Często w wywiadzie jest obecne nadciśnienie tętnicze, a chorobą współistniejącą jest migotanie przedsionków. Dlatego w aspekcie prewencji należy kontrolować wszystkie czynniki ryzyka układu krążenia, również te niedoceniane społecznie, tj. czynniki związane $\mathrm{z}$ cechami zespołu metabolicznego.

\section{Czynniki predysponujące do rozwoju nadciśnienia płucnego}

Nadciśnienie płucne (PH; pulmonary hypertension) jest definiowane jako podwyższone średnie ciśnienie w tętnicy płucnej $\geq 25 \mathrm{mmHg}$ w spoczynku oznaczone w cewnikowaniu prawego serca [38]. Nadciśnienie płucne występuje w przebiegu wielu chorób. Najnowsza klasyfikacja kliniczna nadciśnienia płucnego (pochodząca ze spotkania w Dana Point) obejmuje 5 grup [39]:

Grupa 1 - tętnicze nadciśnienie płucne - jest stanem klinicznym cechującym się obecnością przedwłośniczkowego nadciśnienia płucnego i naczyniowym oporem płucnym $>3$ WU. Obejmuje bardzo niejednorodne stany kliniczne, których wspólną cechą są objawy kliniczne (duszność wysiłkowa, męczliwość) i hemodynamiczne oraz niemal identyczne zmiany patomorfologiczne w mikrokrążeniu płucnym. Jednak przyczyny wiodące do rozwoju tej postaci nadciśnienia płucnego mogą być bardzo różne, poczynając od postaci rodzinnych, postaci związanych $\mathrm{z}$ chorobami tkanki łącznej lub $\mathrm{z}$ wadami przeciekowymi serca, kończąc na zdarzeniach jatrogennych lub toksycznych. Wśród tych ostatnich szczególny problem stanowi dazatynib. Przy ostatecznym rozpoznaniu bardzo ważne jest wykluczenie innych potencjalnych przyczyn przedwłośniczkowego nadciśnienia płucnego (zwłaszcza chorób płuc i zmian zakrzepowo-zatorowych).
Grupa 2 - żylne, czyli pozawłośniczkowe nadciśnienie płucne jest to najczęściej rozpoznawana postać nadciśnienia płucnego. Występuje do $60 \%$ chorych z ciężką dysfunkcją skurczową lewej komory i do 70\% chorych z izolowaną dysfunkcją rozkurczową [40].

Grupa 3 - nadciśnienie płucne przedwłośniczkowe będące powikłaniem chorób płuc i związanej z nimi hipoksji. W ramach diagnostyki tej grupy bardzo pomocne stają się badania czynnościowe układu oddechowego oraz tomografia komputerowa klatki piersiowej. Badanie czynnościowe płuc z oceną DLCO jest zalecane w początkowej ocenie pacjentów z nadciśnieniem płucnym (klasa zaleceń I). HRCT należy rozważyć u wszystkich pacjentów z nadciśnieniem płucnym (klasa zaleceń IIa).

Grupa 4 - nadciśnienie płucne przedwłośniczkowe będące powikłaniem zatorowości płucnej (nadciśnienie płucne zakrzepowo-zatorowe). Zważywszy, że choroba nowotworowa jest istotnym czynnikiem ryzyka zatorowości płucnej, podstawowym celem leczenia przeciwzakrzepowego w onkologii i hematologii jest m.in. zapobieganie rozwojowi tej postaci nadciśnienia płucnego [41].

Grupa 5 - nadciśnienie płucne o etiologii wieloczynnikowej, przedwłośniczkowe lub pozawłośniczkowe sama PBSz może powodować wystąpienie nadciśnienia płucnego o niejasnej lub wieloczynnikowej etiologii [42-46]. Przewlekłe choroby mieloproliferacyjne mogą indukować szereg potencjalnych mechanizmów prowadzących do wzrostu ciśnienia w tętnicy płucnej, takich jak wzrost wyrzutu lewej komory serca, bezpośredni skurcz naczyń płucnych, zdarzenia zakrzepowo-zatorowe, nadciśnienie wrotne czy zastoinowa niewydolność serca [47, 48].

Czynniki ryzyka PAH zidentyfikowane u chorych na PBSz opisane w największej dostępnej analizie opublikowanej przez Shah i wsp. [49] przedstawiono w tabeli IV.

\section{Diagnostyka różnicowa}

Z najnowszych obserwacji wiadomo, że większość pacjentów z PBSz skarży się na męczliwość lub duszność wysiłkową, a wielu doświadcza dyskomfortu związanego z zatrzymywaniem płynów pod postacią obrzęków i wysięków najczęściej do jam opłucnowych. Każdy chory na PBSz ma przynajmniej jeden czynnik ryzyka rozwoju nadciśnienia płucnego, tj. samą mieloproliferacyjną chorobę podstawową. Należy zatem przyjmować zawsze, że u chorego na PBSz może wystąpić więcej niż jedna przyczyna nadciśnienia płucnego, dlatego konieczna jest właściwa diagnostyka różnicowa. Echokardiografia przezklatkowa jest używana w celu ujawnienia skutków przeciążenia prawej komory serca i oszacowania ciśnienia w tętnicy płucnej na podstawie pomiarów wykonywanych metodą Dopplera fali ciągłej. Badanie echokardiograficzne powinno ustalić prawdopodobieństwo nadciśnienia płucnego. Wynik echokardiograficzny jest niezbędny w celu podjęcia decyzji o konieczności wykonania cewnikowania prawego serca.

> U każdego chorego na PBSz z określonym echokardiograficznie pośrednim prawdopodobieństwem nadciśnienia 
Tabela IV - Czynniki ryzyka nadciśnienia plucnego zidentyfikowane u chorych na PBSz - zmodyfikowano na podstawie [49]

Table IV - Pulmonary hypertension (PH) risk factors identified in patients with CML - modified based on [49]

\begin{tabular}{|c|c|}
\hline Przedwłośniczkowe nadciśnienie płucne & Pozawłośniczkowe nadciśnienie płucne \\
\hline $\begin{array}{l}\text { Choroby tkanki łącznej } \\
\text { Żylna choroba zakrzepowo-zatorowa } \\
\text { Choroby płuc } \\
\text { - śródmiąższowe } \\
\text { - obturacyjne (będące najczęściej konsekwencją palenia } \\
\text { papierosów) }\end{array}$ & $\begin{array}{l}\text { Kardiomiopatie } \\
\text { Przebyte zapalenie mieśnia sercowego } \\
\text { Choroby predysponujące do rozwoju skurczowej lub rozkurczowej } \\
\text { dysfunkcji lewej komory serca: } \\
\text { - choroba wieńcowa } \\
\text { - nadciśnienie tętnicze } \\
\text { - cukrzyca } \\
\text { - otyłość } \\
\text { • inne istotne czynniki ryzyka miażdżycy i zawału serca, takie jak: } \\
\text { hipercholesterolemia/ hipertriglyceridemia, palenie papierosów }\end{array}$ \\
\hline
\end{tabular}

płucnego należy rozważyć dalszą diagnostykę, włączając cewnikowanie prawego serca (klasa zaleceń IIa).

> U każdego chorego na PBSz z określonym echokardiograficznie wysokim prawdopodobieństwem nadciśnienia płucnego należy przeprowadzić dalszą, włączając cewnikowanie prawego serca (klasa zaleceń I).

Echokardiografia może być bardzo pomocna w określeniu przyczyny podejrzewanego lub potwierdzonego nadciśnienia płucnego, zwłaszcza gdy chodzi o ujawnienie wady serca, określenie funkcji skurczowej i rozkurczowej lewej komory serca. Diagnostyka różnicowa może być zakończona po badaniu echokardiograficznym, kiedy jest pewność, że wysokie ciśnienie w tętnicy płucnej jest konsekwencją choroby lewego serca. Jednakże w przypadku chorych na PBSz współwystępowanie innych przyczyn przemawiających za przedwłośniczkowym nadciśnieniem płucnym skłania do poszerzania diagnostyki. Zatem pacjent powinien być skierowany do ośrodka referencyjnego w zakresie prowadzenia diagnostyki i leczenia nadciśnienia płucnego. Cewnikowanie prawego serca jest niezbędne do potwierdzenia rozpoznania tętniczego nadciśnienia płucnego (grupa 1) i nadciśnienia płucnego zakrzepowo-zatorowego (grupa 4), a także do oceny wazoreaktywności krążenia płucnego. Z definicji zatem cewnikowanie prawego serca jest konieczne $u$ chorych na PBSz z podejrzeniem (na podstawie objawów klinicznych i echokardiograficznych) nadciśnienia płucnego indukowanego dazatynibem.

\section{Wysięki opłucnowe u chorych na PBSz leczonych dazatynibem}

Najczęstszym niehematologicznym objawem niepożądanym dazatynibu jest występowanie płynu w jamie opłucnej, który w stopniu 3.-4. wg CTC pojawia się u około 5\% pacjentów, a we wszystkich stopniach nasilenia u ponad $20 \%$ chorych [50-53]. Patogeneza tego powikłania nie jest wyjaśniona. Bierze się pod uwagę mechanizmy immunologiczne, a także hamowanie receptora beta dla płytkopochodnego czynnika wzrostu (PDGFR $\beta$ ), który ulega ekspresji na perycytach i jest zaangażowany $\mathrm{w}$ proces angiogenezy [51]. Do czynników zwiększających ryzyko pojawienia się płynu w jamie opłucnej należą: wyższa dawka dazatynibu i schemat dawkowania co $12 \mathrm{~h}$, starszy wiek pacjenta, bardziej zaawansowana faza choroby, choroby serca i płuc w wywiadzie, hipercholesterolemia, nadciśnienie tętnicze, wysypka skórna podczas leczenia dazatynibem i choroby autoimmunologiczne w wywiadzie [50-53]. Należy podkreślić, że wysięk opłucnowy może być późnym powikłaniem terapii, a opisywane mediany czasu do jego wystąpienia wynoszą od 11 do około 30 miesięcy [52, 53]. Wysięk w jamie opłucnej wymaga szybkiej diagnostyki i wdrożenia odpowiedniego leczenia. Chorego przyjmującego dazatynib należy poinformować o konieczności zgłaszania duszności, zwiększonej męczliwości czy kaszlu. U pacjentów z takimi objawami zaleca się wykonanie badania radiologicznego klatki piersiowej. Po potwierdzeniu wysięku w jamie opłucnej w badaniu radiologicznym należy przerwać leczenie dazatynibem do czasu ustąpienia objawów. Ponadto należy rozważyć zastosowanie leków moczopędnych i/lub, np. prednizonu w dawce 20$50 \mathrm{mg} / \mathrm{d}$ podawanej przez 3-4 dni, z następczą redukcją do $20 \mathrm{mg} / \mathrm{d}$ podawanaych przez kolejne 3-4 dni [54-56]. Podawanie leków moczopędnych można kontynuować dłużej w celu zapobieżenia ponownego wystąpienia wysięku. Wysięk w jamie opłucnej w stopniu nasilenia 3. lub 4. wymaga drenażu jamy opłucnowej, tlenoterapii, włączenia glikokortykosteroidów oraz leków moczopędnych. Po wyleczeniu pierwszego epizodu wysięku w stopniu nasilenia 1.2. zaleca się wznowienie podawania dazatynibu w tej samej dawce. W przypadku nawrotu wskazany jest powrót do dawki niższej. U chorych w fazie przewlekłej PBSz, którzy otrzymywali dawkę $100 \mathrm{mg}$ raz na dobę, zaleca się zmniejszenie dawki do $80 \mathrm{mg}$ raz na dobę, z kolejnym zmniejszeniem dawki do $50 \mathrm{mg}$ raz na dobę. W przypadku wystąpienia płynu w stopniu 3. lub 4. leczenie należy wznowić w dawce zmniejszonej o jeden poziom. Kolejny ciężki epizod wysięku w jamie opłucnej wymaga stałego odstawienia dazatynibu i zmiany na inny IKT [54-56]. Zwiększona ilość płynu w jamie opłucnowej w trakcie leczenia dazatynibem może mieć charakter zarówno wysięku, jak i przesięku. Jeśli wykonywana jest punkcja opłucnej, uzyskany płyn należy poddać badaniu biochemicznemu, mikrobiologicznemu, cytologicznemu i innym w razie potrzeby, by wykluczyć inną niż polekowa przyczynę obecności płynu. Należy zaznaczyć, że u większości chorych na PBSz leczonych dazatynibem pojawienie się $\mathrm{PAH}$ jest poprzedzone wystąpieniem wysięku opłucnowego [57]. Dlatego też, u chorych, u których stwierdza się płyn w jamie opłucnej w trakcie leczenia 
dazatynibem, należy wykonać badanie echokardiograficzne serca. Szybkie wdrożenie właściwego postępowania terapeutycznego, w większości przypadków umożliwia kontynuację terapii dazatynibem.

\section{Interakcje lekowe $\mathrm{z}$ inhibitorami kinaz tyrozynowych}

\section{Interakcje IKT z lekami stosowanych $w$ terapii chorób krążenia}

Imatynib jest metabolizowany głównie przez podjednostkę CYP3A4 cytochromu p450 (jest jednocześnie jego inhibitorem), w mniejszym stopniu przez podjednostki CYP1A2, CYP2C9, CYP2C19, CYP2D6 i CYP3A5 [58]. Imatynib jest substratem białka kationowego, które aktywnie wprowadza ten lek do komórek (hOCT1; human organic cationic transporter-1), białek oporności wielolekowej (Pgp; P-glycoprotein) i ABCG2 [59, 60], choć jego rola w interakcji $\mathrm{z}$ ostatnim białkiem nie jest jasna wobec sprzecznych doniesień na temat hamowania lub indukowania tej proteiny. Nilotynib metabolizowany jest przez CYP3A4, hamuje podjednostki CYP2C8, CYP2C9, CYP2D6, CYP3A4, białko glukoronylotransferazy UDP (UGT1A1, UDP-glucuronylotransferase 1-1), jest substratem białka Pgp i ABCG2 oraz induktorem (in vitro) podjednostki CYP2B6 [59, 61]. Dazatynib podlega przemianom przez CYP3A4 (jest jego oraz białka CYP2C8 inhibitorem), jest także substratem białek PgP i ABCG2 $[62,63]$. Hamowanie aktywności białek $\mathrm{z}$ rodziny CYP3A przez IKT może zwiększać stężenie w osoczu leków metabolizowanych także przez ten cytochrom i nasilać ich działania niepożądane. Leki będące induktorami białek $\mathrm{z}$ rodziny CYP3A zmniejszają stężenie IKT w osoczu (co może skutkować spadkiem stężenia IKT poniżej terapeutycznego i zmniejszeniem skuteczności terapii) i vice versa inhibitory CYP3A mogą to stężenie zwiększać, co niesie ze sobą ryzyko nasilenia działań niepożądanych IKT. Zahamowanie aktywności hOCT-1 ogranicza transport aktywny imatynibu do komórek, przez co zmniejsza stężenie wewnątrzkomórkowe tego leku, natomiast zwiększenie aktywności białek Pgp i ABCG2 doprowadza do usunięcia IKT z komórek i zmniejszenia ich wewnątrzkomórkowej koncentracji. Interakcje leków często stosowanych w leczeniu chorób krążenia $\mathrm{z}$ imatynibem, nilotynibem i dazatynibem przedstawiono w tabeli V. Leki blokujące kanały wapniowe u chorych otrzymujących IKT powinny być stosowane z dużą ostrożnością. Werapamil, nifedypina, diltiazem i amlodypina hamują aktywność CYP3A4 i białka Pgp, przez co zwiększają stężenie w osoczu imatynibu, nilotynibu i dazatynibu. Ponadto wszystkie IKT, będąc inhibitorami CYP3A4 (a imatynib i nilotynib są dodatkowo inhibitorami Pgp), zwiększają stężenie blokerów kanałów wapniowych w osoczu - dlatego jednoczesne stosowanie tych leków może doprowadzić do pojawienia się ich działań niepożądanych. Z dużą ostrożnością powinny być stosowane leki antyarytmiczne (amiodaron, chinidyna), gdyż zwiększają stężenie w osoczu imatynibu, nilotynibu i dazatynibu, a IKT zwiększają ekspozycję na amiodaron i chinidynę. Dodatkowe niebezpieczeństwo ich stosowania wynika $\mathrm{z}$ wydłużania odcinka QT (może pojawić się efekt synergistyczny z nilotynibem i dazatynibem) - wymagane jest monitorowanie EKG. Spośród leków diuretycznych w interakcje z IKT nie wchodzą furosemid i hydrochlorotiazyd. Imatynib i nilotynib zwiększają ekspozycję na torasemid, a spironolakton zwiększa stężenie imatynibu i dazatynibu w osoczu. Wśród $\beta$ blokerów jedynym lekiem niewchodzącym w interakcje z IKT jest atenolol. Wszystkie IKT zwiększają w osoczu stężenie metoprololu i bisoprololu, a imatynib i dazatynib zwiększają ekspozycję na carvedilol, który podwyższa stężenie imatynibu i dazatynibu. Spośród inhibitorów enzymu konwertującego ramipryl nie wchodzi w interakcje $\mathrm{z}$ IKT. Lisinopryl nie wchodzi $\mathrm{w}$ interakcje $\mathrm{z}$ nilotynibem (imatynib zwiększa jego stężenie, a on sam zwiększa stężenie imatynibu i dazatynibu). Imatynib i nilotynib zwiększają stężenie kaptoprylu i enalaprylu, natomiast podawanie tych leków zwiększa stężenie imatynibu i dazatynibu. Wśród inhibitorów angiotenzyny II kandesartan nie wchodzi w interakcje z IKT. Wszystkie natomiast IKT zwiększają stężenie losartanu w osoczu, a jego podawanie powoduje zwiększenie stężenia osoczowego imatynibu i dazatynibu. Imatynib zmniejsza wchłanianie digoksyny, natomiast jej podawanie skutkuje wzrostem stężenia dazatynibu i nilotynibu i wydłużeniem odcinka QT - wymagane jest monitorowanie EKG. Nitrogliceryna i molsydomina nie wchodzą w interakcje z IKT. Stężenie nitratów jest natomiast zwiększane przez imatynib, dazatynib oraz nilotynib. Prawastatyna i rosuwastatyna należą do inhibitorów reduktazy HMG-CoA, które nie wchodzą w interakcje z IKT. Zarówno imatynib, dazatynib, jak i nilotynib zwiększają stężenie osoczowe simwastatyny i atorwastatyny, natomiast ich podawanie zwiększa ekspozycję na imatynib i dazatynib. Wszystkie IKT zwiększają stężenie w osoczu klopidogrelu, jednak równocześnie zmniejszają jego bioaktywację. Imatynib i nilotynib nasila działanie przeciwzakrzepowe doustnych antykoagulantów, co wymaga ściślejszej kontroli czasu protrombinowego (PT: INR). Poza heparyną standardową, która zwiększa stężenie imatynibu w osoczu, heparyny nie wchodzą w interakcje z IKT. U chorych otrzymujących dazatynib jednoczesne stosowanie leków przeciwpłytkowych, doustnych koagulantów, heparyn standardowych oraz drobnocząsteczkowych może doprowadzić do nasilenia skutków małopłytkowości [64]. Podsumowując, wszystkie wymienione powyżej blokery kanałów wapniowych, leki antyarytmiczne, większość $\beta$-blokerów, inhibitorów enzymu konwertującego, inhibitorów angiotenzyny II, inhibitorów reduktazy HMG-CoA, prekursorów tlenku azotu, digoksyna, klopidogrel, doustne antykoagulanty i heparyna standardowa wchodzą we wzajemne interakcje z IKT i należy wykazać dużą ostrożność w ich stosowaniu u chorych otrzymujących IKT. Do leków, które ze względu na brak interakcji z IKT są szczególnie zalecane w leczeniu chorób układu krążenia, należą: z grupy diuretyków furosemid i hydrochlorotiazyd, z $\beta$-blokerów atenolol, spośród inhibitorów enzymu konwertującego ramipryl, kandesartan z grupy inhibitorów angiotenzyny II, nitrogliceryna lub molsydomina jako substancje uwalniające tlenek azotu, prawastatyna lub rosuwastatyna spośród inhibitorów reduktazy HMG-CoA oraz heparyny drobnocząsteczkowe z leków przeciwzakrzepowych. 
Tabela V - Interakcje leków stosowanych w leczeniu chorób sercowo - naczyniowych z IKT [64]

Table V - Interactions of selected medicaments used in therapy of cardio-vascular disorders with TKIs [64]

\begin{tabular}{|c|c|c|c|}
\hline Lek & Imatynib & Dazatynib & Nilotynib \\
\hline \multicolumn{4}{|c|}{ Blokery kanałów wapniowych } \\
\hline Werapamil, Nifedypina, & Imatynib $\uparrow$ & Dazatynib $\uparrow$ & Nilotynib $\uparrow$ \\
\hline Diltiazem, Amlodypina & Ca-bloker $\uparrow$ & Ca-bloker $\uparrow$ & Ca-bloker $\uparrow$ \\
\hline \multicolumn{4}{|c|}{ Leki antyarytmiczne } \\
\hline \multirow[t]{3}{*}{ Amiodaron, chinidyna } & Imatynib $\uparrow$ & Dazatynib $\uparrow$ & Nilotynib $\uparrow$ \\
\hline & Amiodaron $\uparrow$ & Amiodaron $\uparrow$ & Amiodaron $\uparrow$ \\
\hline & Chinidyna $\uparrow$ & Chinidyna $\uparrow$ & Chinidyna $\uparrow$ \\
\hline \multicolumn{4}{|c|}{ Diuretyki } \\
\hline Furosemid & - & - & - \\
\hline Hydrochlorotiazyd & - & - & - \\
\hline Spironolakton & Imatynib $\uparrow$ & Dazatynib $\uparrow$ & \\
\hline Torasemid & Torasemid $\uparrow$ & - & Torasemid $\uparrow$ \\
\hline \multicolumn{4}{|c|}{$\beta$-blokery } \\
\hline Atenolol & - & - & - \\
\hline Metoprolol & Metoprolol $\uparrow$ & Metoprolol $\uparrow$ & Metoprolol $\uparrow$ \\
\hline Bisoprolol & Bisoprolol $\uparrow$ & Bisoprolol $\uparrow$ & Bisoprolol $\uparrow$ \\
\hline Carvedilol & Imatynib $\uparrow$ & Dazatynib $\uparrow$ & \\
\hline & Carvedilol $\uparrow$ & & Carvedilol $\uparrow$ \\
\hline \multicolumn{4}{|c|}{ Inhibitory enzymu konwertującego } \\
\hline Ramipryl & - & - & - \\
\hline Kaptopryl & Imatynib $\uparrow$ & Dazatynib $\uparrow$ & \\
\hline & Kaptopryl $\uparrow$ & & Kaptopryl $\uparrow$ \\
\hline Enalapryl & Imatynib $\uparrow$ & Dazatynib $\uparrow$ & \\
\hline & Enalapryl $\uparrow$ & & Enalapryl $\uparrow$ \\
\hline Lisinopryl & Imatynib $\uparrow$ & Dazatynib $\uparrow$ & - \\
\hline & Lisinopryl $\uparrow$ & & \\
\hline \multicolumn{4}{|c|}{ Inhibitory angiotenzyny II } \\
\hline Kandesartan & - & - & - \\
\hline Losartan & Imatynib $\uparrow$ & Dazatynib $\uparrow$ & \\
\hline & Losartan $\uparrow$ & Losartan $\uparrow$ & Losartan $\uparrow$ \\
\hline \multicolumn{4}{|c|}{ Glikozydy nasercowe } \\
\hline Digoksyna & Digoksyna $\downarrow$ & $\begin{array}{l}\text { Dazatynib } \uparrow \\
\text { odc QT } \uparrow ! ! !\end{array}$ & $\begin{array}{l}\text { Nilotynib } \uparrow \\
\text { odc QT } \uparrow ! ! !\end{array}$ \\
\hline \multicolumn{4}{|c|}{ Prekursory tlenku azotu (NO) } \\
\hline Nitrogliceryna, molsydomina & - & - & - \\
\hline Isosorbidmononitrate & Isosorbidmononitrate $\uparrow$ & Isosorbidmononitrate $\uparrow$ & Isosorbidmononitrate $\uparrow$ \\
\hline Isosorbiddinitrate & Isosorbiddinitrate $\uparrow$ & Isosorbiddinitrate $\uparrow$ & Isosorbiddinitrate $\uparrow$ \\
\hline \multicolumn{4}{|c|}{ Inhibitory reduktazy HMG-CoA } \\
\hline Pravastatin, Rosuvastatin & - & - & - \\
\hline Simvastatin, Atorvastatin & Imatynib $\uparrow$ & Dazatynib $\uparrow$ & \\
\hline & Simvastatin $\uparrow$ & Simvastatin $\uparrow$ & Simvastatin $\uparrow$ \\
\hline & Atorvastatin $\uparrow$ & Atorvastatin $\uparrow$ & Atorvastatin $\uparrow$ \\
\hline \multicolumn{4}{|c|}{ Leki przeciwpłytkowe } \\
\hline Klopidogrel & Klopidogrel $\uparrow$ & $\begin{array}{l}\text { Klopidogrel } \uparrow \\
\text { nasilenie skutków } \\
\text { małopłytkowości }\end{array}$ & Klopidogrel $\uparrow$ \\
\hline \multicolumn{4}{|c|}{ Doustne antykoagulanty } \\
\hline Acenokumarol & $\begin{array}{l}\text { nasilenie działania } \\
\text { przeciwzakrzepowego }\end{array}$ & $\begin{array}{l}\text { nasilenie skutków } \\
\text { małopłytkowości }\end{array}$ & $\begin{array}{l}\text { nasilenie działania } \\
\text { przeciwzakrzepowego }\end{array}$ \\
\hline Warfaryna & $\begin{array}{l}\text { nasilenie działania } \\
\text { przeciwzakrzepowego }\end{array}$ & $\begin{array}{l}\text { nasilenie skutków } \\
\text { małopłytkowości }\end{array}$ & $\begin{array}{l}\text { nasilenie działania } \\
\text { przeciwzakrzepowego }\end{array}$ \\
\hline \multicolumn{4}{|c|}{ Heparyny } \\
\hline Heparyna standardowa & Imatynib $\uparrow$ & $\begin{array}{l}\text { nasilenie skutków } \\
\text { małopłytkowości }\end{array}$ & - \\
\hline Enoksaparyna, Nadroparyna, & - & $\begin{array}{l}\text { nasilenie skutków } \\
\text { małopłytkowości }\end{array}$ & - \\
\hline Dalteparyna & & & \\
\hline
\end{tabular}


Tabela VI - Interakcje doustnych leków przeciwhiperglikemicznych z IKT [64] Table VI - Interactions of oral antihyperglycemic drugs with TKIs [64]

\begin{tabular}{|c|c|c|c|}
\hline Lek & Imatynib & Dazatynib & Nilotynib \\
\hline Insuliny & - & - & - \\
\hline Metformina & Imatynib $\downarrow$ & - & - \\
\hline Akarboza & - & - & - \\
\hline Pochodne sulfonylomocznika & Imatynib $\uparrow$ & Dazatynib $\uparrow$ & \\
\hline (Glibenklamid, Gliklazyd, Glimepiryd, Glipizyd) & $\begin{array}{l}\text { Glibenklamid, Gliklazyd, } \\
\text { Glimepiryd } \uparrow\end{array}$ & $\begin{array}{l}\text { Glibenklamid, Gliklazyd, } \\
\text { Glimepiryd } \uparrow\end{array}$ & $\begin{array}{l}\text { Glibenklamid, Gliklazyd, } \\
\text { Glimepiryd } \uparrow\end{array}$ \\
\hline \multicolumn{4}{|l|}{ Pochodne tiazolidynodionu (glitazony) } \\
\hline Pioglitazon & Pioglitazon $\uparrow$ & Pioglitazon $\uparrow$ & Pioglitazon $\uparrow$ \\
\hline \multicolumn{4}{|l|}{ Leki inkretynowe } \\
\hline Linagliptyna, & Imatynib $\uparrow$, Linagliptyna $\uparrow$ & Dazatynib $\uparrow$, Linagliptyna $\uparrow$ & Nilotynib $\uparrow$, Linagliptyna $\uparrow$ \\
\hline Sitagliptyna, & Sitagliptyna $\uparrow$ & Sitagliptyna $\uparrow$ & Sitagliptyna $\uparrow$ \\
\hline Saksagliptyna, & Saksagliptyna $\uparrow$ & Saksagliptyna $\uparrow$ & Saksagliptyna $\uparrow$ \\
\hline Wildagliptyna & - & - & - \\
\hline \multicolumn{4}{|l|}{ Inhibitory SGLT2 (flozyny) } \\
\hline Dapagliflozyna, & - & - & - \\
\hline Kanagliflozyna & Imatynib $\uparrow$, Kanagliflozyna $\uparrow$ & Dazatynib $\uparrow$, Kanagliflozyna $\uparrow$ & Nilotynib $\uparrow$, Kanagliflozyna $\uparrow$ \\
\hline
\end{tabular}

\section{Interakcje doustnych leków przeciwcukrzycowych z IKT}

Preparaty insuliny nie wykazują żadnych interakcji z obecnie stosowanymi w leczeniu PBSz IKT [64]. Metformina stosowana $\mathrm{u}$ chorych na cukrzycę zmniejsza wewnątrzkomórkowe stężenie imatynibu poprzez hamowanie aktywności hOCT-1. Powyższy wpływ należy wziąć pod uwagę u pacjentów, którzy nie uzyskują optymalnej odpowiedzi na leczenie imatynibem, i rozważyć modyfikację leczenia przeciwcukrzycowego lub zwiększenie dawki imatynibu do $600 \mathrm{mg} / \mathrm{d}$, gdyż pozwala ona na uzyskanie terapeutycznego stężenia imatynibu w komórkach docelowych [65]. Ostrożność należy zachować podczas leczenia chorych na cukrzycę pozostałymi lekami doustnymi (Tab. VI). Imatynib, nilotynib, jak i dazatynib, będąc inhibitorami podjednostki CYP 3A4 cytochromu P450, zwiększają ekspozycję na te leki, co może doprowadzić nie tylko do zwiększenia ich działania hipoglikemizującego, ale także do nasilenia ich działań niepożądanych [64]. Pochodne sulfonylomocznika są substratami dla podjednostki CYP2C9 cytochromu P450, dlatego jej inhibitory (imatynib, nilotynib) mogą zwiększać ekspozycję na te leki [66]. Glibenklamid hamuje aktywność glikoproteiny oporności wielolekowej, która aktywnie usuwa z komórek dazatynib, przez co zwiększa się jego stężenie wewnątrzkomórkowe. Dlatego u chorych leczonych skojarzeniem obu tych leków należy zachować szczególną ostrożność i z należytą starannością monitorować ich działania niepożądane. Gliklazyd jest metabolizowany przez CYP2C9 oraz częściowo przez CYP3A4, jego stosowanie może zwiększać ekspozycję na IKT [67, 68]. Linagliptyna jest słabym inhibitorem izoenzymu CYP3A4, nie jest induktorem ani inhibitorem innych izoenzymów cytochromu P-450, jednak jej podawanie zwiększa ekspozycję na imatynib, dazatynib i nilotynib, co może prowadzić do nasilenia działań niepożądanych tych leków. Badania in vitro wykazały, że podjednostki CYP3A4 i, w mniejszym stopniu, CYP2C8 metabolizują sitagliptynę. Lekiem o minimalnym potencjale interakcji z innymi jest vildagliptyna. Najprawdopodobniej nie jest ona substratem dla CYP3A4, CYP2C8 i CYP2C9 [69]. Podobnie dapaglifozyna nie jest metabolizowana przez cytochrom P450 [70]. Natomiast kanagliflozyna jest transportowana przez białko Pgp, białko oporności raka piersi (BCRP; Breast Cancer Resistance Protein), jej stężenie ulega zwiększeniu pod wpływem jednoczesnego stosowania substratów CYP3A4. W badaniach in vitro wykazano, że jest słabym inhibitorem CYP2B6, CYP2C8, CYP2C9 i CYP3A4 [71].

\section{Podsumowanie}

Leczenie przewlekłej białaczki szpikowej stało się w ostatnich 16 latach bardzo skuteczne za sprawą zastosowania inhibitorów kinaz tyrozynowych. Większość pacjentów osiąga odpowiedzi cytogenetyczne i molekularne, a odsetki wieloletnich przeżyć całkowitych oscylują wokół wartości 85-93\% [72]. W przebiegu długotrwałej terapii IKT wyłania się szereg problemów klinicznych, których źródeł można upatrywać w dwóch istotnych zjawiskach. Wraz z wydłużaniem czasu leczenia i jednocześnie przeżycia chorych na PBSz dochodzi do starzenia się populacji otrzymującej IKT, pojawiają się zatem choroby współistniejące, których częstość występowania wzrasta wraz z wiekiem (jak np. miażdżyca i jej powikłania, zaburzenia w przemianach lipidów i glukozy, zastoinowa niewydolność krążenia itd.). Drugi problem polega na pojawianiu się działań niepożądanych IKT, które niejednokrotnie dają znać o sobie po dłuższym okresie leczenia i na które zaczęto zwracać uwagę stosunkowo niedawno (jak np. zaburzenia metabolizmu glukozy i insuliny oraz zaburzenia przemian lipidów, czego konsekwencją może być np. nasilanie lub indukowanie choroby okluzyjnej naczyń obwodowych przez nilotynib, wywoływanie powikłań zatorowo-zakrzepowych przez ponatynib, wywoływanie wysięków opłucnowych i zaburzeń funkcji układu krążenia wiodących do niewydolności krążenia lub powstania nadciśnienia płucnego w trakcie leczenia dazatynibem). Coraz większe znaczenie dla powodzenia terapii ma dobór optymalnego leku, który nie tylko powinien być dokonany na podstawie analizy przyczyn oporności na dotychczasowe leczenie (np. ocena mutacji domeny kinazy 
ABL, możliwość stosowania się pacjenta do zaleceń), ale także winien brać pod uwagę profil toksyczności danego IKT oraz choroby współistniejące obciążające pacjenta. Innym niezwykle istotnym zagadnieniem pojawiającym się w trakcie długotrwałego leczenia PBSz jest problem możliwych wzajemnych interakcji pomiędzy IKT i wdrażanymi do terapii chorób współistniejących innymi lekami. W świetle przytoczonych powyżej danych zasadne wydaje się sformułowanie wniosku, że leczenie przewlekłej białaczki szpikowej powinno być pozostawione w rękach doświadczonego lekarza hematologa, świadomego skuteczności i profilu bezpieczeństwa stosowanych leków, ale także zagrożeń płynących z długotrwałej terapii inhibitorami kinaz tyrozynowych. Leczenie takie powinno opierać się na współpracy ze specjalistami innych dziedzin medycyny (takich jak diabetolog, kardiolog, pulmonolog) w celu zapewnienia optymalnych jego wyników nie tylko w aspekcie terapii przeciwnowotworowej, ale także chorób współistniejących.

\section{Wkład autorów/Authors' contributions}

Według kolejności.

\section{Konflikt interesu/Conflict of interest}

Nie występuje.

\section{Finansowanie/Financial support}

Nie występuje.

\section{Etyka/Ethics}

Treści przedstawione $\mathrm{w}$ artykule są zgodne $\mathrm{z}$ zasadami Deklaracji Helsińskiej, dyrektywami EU oraz ujednoliconymi wymaganiami dla czasopism biomedycznych.

\section{PIŚMIEN I C T W O/REFERENCES}

[1] IDF Altas, 7 edycja 2013.

[2] Zalecenia kliniczne dotyczące postępowania u chorych na cukrzycę 2015. Diabetologia Kliniczna 2015; 4; Supl. A: A3.

[3] Raport. Cukrzyca. Ukryta Pandemia. Edycja 2014.

[4] Kantarjian HM, Hochhaus A, Saglio G, et al. Nilotinib versus imatinib for the treatment of patients with newly diagnosed chronic phase, Philadelphia chromosomepositive, chronic myeloid leukaemia: 24-month minimum follow-up of the phase 3 randomisedENESTnd trial. Lancet Oncol 2011;12:841-851.

[5] Alberti KGMM, Eckel RH, Grundy SM, et al. Harmonizing the Metabolic SyndromeA Joint Interim Statement of the International Diabetes Federation Task Force on Epidemiology and Prevention; National Heart, Lung, and Blood Institute; American Heart Association; World Heart Federation; International Atherosclerosis Society; and International Association for the Study of Obesity. Circulation 2009;120:1640-1645.
[6] Zalecenia kliniczne dotyczące postępowania u chorych na cukrzycę 2015. Diabetologia Kliniczna 2015; 4; Supl. A: A7.

[7] Zalecenia kliniczne dotyczące postępowania u chorych na cukrzycę 2016 Stanowisko Polskiego Towarzystwa Diabetologicznego. Diabetologia Kliniczna 2016; Tom 5, Supl. A.

[8] Frołow M, Masłowski L. Przewlekłe niedokrwienie kończyn dolnych w Interna Szczeklika 2014, wyd. Kraków: Medycyna Praktyczna; 2014: 465-470.

[9] Neubauer-Geryk J, Bieniaszewski L. Wskaźnik kostka-ramię w ocenie pacjentów z ryzykiem miażdżycy. Choroby serca i Naczyń 2007;1:1-5.

[10] Fontaine R, Kim M, Kieny R. Surgical treatment of peripheral circulation disorders. HelvChirActa 1954;21:499-533.

[11] Kim TD, Rea D, Schwarz M, et al. Peripheral artery occlusive disease in chronic phase chronic myeloid leukemia patients treated with nilotinib or imatinib. Leukemia 2013;27:1316-1321.

[12] Giles FJ, Mauro MJ, Hong F, et al. Rates of peripheral arterial occlusive disease in patients with chronic myeloid leukemia in the chronic phase treated with imatinib, nilotinib, or non-tyrosine kinase therapy: a retrospective cohort analysis. Leukemia 2013;27:1310-1315.

[13] Le Coutre P, Rea D, Abruzzese E, et al. Severe peripheral arterial disease during nilotinib therapy. J Natl Cancer Inst 2011;103:1347-1348. 7.

[14] Cortes JE, Kim DW, Pinilla-Ibarz J, et al. A phase 2 trial of ponatinib in Philadelphia chromosome-positive leukemias. N Engl J Med 2013;369:1783-1796. 7.

[15] Kantarjian HM, Cortes JE, Kim DW, et al. Bosutinib safety and management of toxicity in leukemia patients with resistance or intolerance to imatinib and other tyrosine kinase inhibitors. Blood 2014;123:1309-1318. 27.

[16] Valent P, Hadzijusufovic E, Schernthaner GH, et al. Vascular safety issues in CML patients treated with BCR/ABL1 kinase inhibitors. Blood 2015;125:901-906. 5.

[17] McMurray JJ, Adamopoulos S, Anker SD, et al. ESC Committee for Practice Guidelines. ESC Guidelines for the diagnosis and treatment of acute and chronic heart failure 2012: The Task Force for the Diagnosis and Treatment of Acute and Chronic Heart Failure 2012 of the European Society of Cardiology. Developed in collaboration with the Heart Failure Association (HFA) of theESC. Eur Heart J 2012;33(14):1787-1847.

[18] Galiè N, Humbert M, Vachiery JL, et al. ESC/ERS Guidelines for the diagnosis and treatment of pulmonary hypertension: The Joint Task Force for the Diagnosis and Treatment of Pulmonary Hypertension of the European Society of Cardiology (ESC) and the European Respiratory Society (ERS): Endorsed by: Association for European Paediatric and Congenital Cardiology (AEPC), International Society for Heart and Lung Transplantation (ISHLT). Eur Heart J 2016;37(1):67-119.

[19] Chen MH, Kerkelä R, Force T. Mechanisms of cardiac dysfunction associated with tyrosine kinase inhibitor cancer therapeutics. Circulation 2008;118(1):84-95.

[20] Francis J, Ahluwalia MS, Wetzler M, et al. Reversible cardiotoxicity with tyrosine kinase inhibitors. Clin Adv Hematol Oncol 2010;8(2):128-132.

[21] Kerkela R, Grazette L, Yacobi R, et al. Cardiotoxicity of the cancer therapeutic agent imatinibmesylate. Nat Med 2006;12:908-916.

[22] Breccia M. Is imatinib-related cardiotoxicity still an open issue? Leuk Res 2011;35:34-35.

[23] Atallah E, Durand JB, Kantarjian H, et al. Congestive heart failure is a rare event in patients receiving imatinib therapy. Blood 2007;110(4):1233-1237. 
[24] Yeh ET, Bickford CL. Cardiovascular complications of cancer therapy: incidence, pathogenesis, diagnosis, and management. J Am CollCardiol 2009;53(24):2231-2247.

[25] Breccia M, Efficace F, Alimena G, et al. Progressive arterial occlusive disease (PAOD) and pulmonary hypertension (PAH) as new advers events of second generation TKIs in CML treatment: who's afraid of the big bad wolf? Leuk Res 2012;36:813-814.

[26] Breccia M, Alimena G. Occurrence and current management of side effects in chronic myeloid leukemia patients treated frontline with tyrosine kinase inhibitors. Leuk Res 2013;37(6):713-720.

[27] Kantarjian H, Shah NP, Cortes JE, et al. Dasatinib or imatinib in newly diagnosed chronic-phase chronic myeloid leukemia: 2-year follow-up from a randomized phase 3 trial (DASISION). Blood 2012;119:1123-1129.

[28] Montani D, Bergot E, Günther S, et al. Pulmonary arterial hypertension in patients treated by dasatinib. Circulation 2012;125:2128-2137.

[29] Quintas-Cradama A, Kantarjian H, O'Brien S, et al. Pleural effusion in patients with chronic myelogenous leukemia treated with dasatinib after imatinib failure. J Clin Oncol 2007;25:3908-3914.

[30] Kim TD, le Coutre P, Schwarz M, et al. Clinical cardiac safety profile of nilotinib. Haematologica 2012;97(6):883-889.

[31] Szmit S. Is dasatinib-related pulmonary hypertension a clinical concern? Future Oncol 2015;11(18):2491-2494.

[32] Schocken DD, Benjamin EJ, Fonarow GC, et al. American Heart Association Council on Epidemiology and Prevention; American Heart Association Council on Clinical Cardiology; American Heart Association Council on Cardiovascular Nursing; American Heart Association Council on High Blood Pressure Research; Quality of Care and Outcomes Research Interdisciplinary Working Group; Functional Genomics and Translational Biology Interdisciplinary Working Group. Prevention of heart failure: a scientific statement from the American Heart Association Councils on Epidemiology and Prevention, Clinical Cardiology, Cardiovascular Nursing, and High Blood Pressure Research; Quality of Care and Outcomes Research Interdisciplinary Working Group; and Functional Genomics and Translational Biology Interdisciplinary Working Group. Circulation 2008 May 13;117(19):2544-2565.

[33] Tinsley SM. Safety profiles of second-line tyrosine kinase inhibitors in patients with chronic myeloid leukaemia. J ClinNurs 2010;19(9-10):1207-1218.

[34] Vachiery JL, Adir Y, Barbera JA, et al. Pulmonary hypertension due to left heart disease. J Am CollCardiol 2013;62:D100-D108.

[35] Khush KK, Tasissa G, Butler J, et al. Effect of pulmonary hypertension on clinical outcomes in advanced heart failure: analysis of the Evaluation Study of Congestive Heart Failure and Pulmonary Artery Catheterization Effectiveness (ESCAPE) database. Am Heart J 2009;157:1026-1034.

[36] Borlaug BA, Paulus WJ. Heart failure with preserved ejection fraction: pathophysiology, diagnosis, and treatment. Eur HeartJ 2011;32:670-679.

[37] Paulus WJ, Tschope C, Sanderson JE, et al. How to diagnose diastolic heart failure: a consensus statement on the diagnosis of heart failure with normal left ventricular ejection fraction by the Heart Failure and Echocardiography Associations of the European Society of Cardiology. Eur Heart J 2007;28:2539-2550.

[38] Galie N, Hoeper MM, Humbert M, et al. Guidelines for the diagnosis and treatment of pulmonary hypertension. EurRespir J 2009;34:1219-1263.

[39] Simonneau G, Robbins I, Beghetti M, et al. Updated clinical classificationof pulmonary hypertension. J Am Coll Cardiol 2009;54:S43-S54.
[40] Ghio S, Gavazzi A, Campana C, et al. Independent and additive prognostic value of right ventricular systolic function and pulmonary artery pressure in patients with chronic heart failure. J Am Coll Cardiol 2001;37:183-188.

[41] Mandalà M, Falanga A, Roila F. ESMO Guidelines Working Group. Management of venous thromboembolism (VTE) in cancer patients: ESMO Clinical Practice Guidelines. Ann Oncol 2011;22(Suppl 6):vi85-vi92.

[42] García-Manero G, Schuster SJ, Patrick H, et al. Pulmonary hypertension in patients with myelofibrosis secondary to myeloproliferative diseases. Am J Hematol 1999;60:130-135.

[43] Dingli D, Utz JP, Krowka MJ, et al. Unexplained pulmonary hypertension in chronic myeloproliferative disorders. Chest 2001;120:801-808.

[44] Altintas A, Karahan Z, Pasa S, et al. Pulmonary hypertension in patients with Essentials thrombocythemia and reactive hrombocytosis. Leuk Lymphoma 2007;48:1981-1987.

[45] Garypidou V, Vakalopoulou S, Dimitriadis D, et al. Incidence of pulmonary hypertension in patients with chronic myeloproliferative disorders. Haematologica 2004;89:245-246.

[46] Gupta R, Perumandla S, Patsiornik Y, et al. Incidence of pulmonary hypertension in patients with chronic myeloproliferative disorders. J Natl Med Assoc 2006;98:1779-1782.

[47] Guilpain P, Montani D, Damaj G, et al. Pulmonary hypertension associated with myeloproliferative disorders: a retrospective study of ten cases. Respiration 2008;76:295-302.

[48] Adir Y, Humbert M. Pulmonary hypertension in patients with chronic myeloproliferative disorders. Eur Respir J 2010;35:1396-1406.

[49] Shah NP, Wallis N, Farber HW, et al. Clinical features of pulmonary arterial hypertension in patients receiving dasatinib. Am J Hematol 2015;90(11):1060-1064.

[50] Valent P. Severe adverse events associated with the use of second-line BCR/ABL tyrosine kinase inhibitors: preferential occurrence in patients with comorbidities. Haematologica 2011;96:1395-1397.

[51] de Lavallade H, Punnialingam S, Milojkovic D, et al. Pleural effusions in patients with chronic myeloid leukaemia treated with dasatinib may have an immune-mediated pathogenesis. Br J Haematol 2008;141:745-747.

[52] Góra-Tybor J, Mędraś E, Całbecka M, et al. Real-life comparison of severe vascular events and other nonhematological complications in patients with chronic myeloid leukemia undergoing second-line nilotinib or dasatinib treatment. LeukLymphoma 2015;56:2309-2314.

[53] Latagliata R, Breccia M, Fava C, et al. Incidence, risk factors and management of pleural effusion during dasatinib treatment In unselected elderly patients with chronic myelogenous leukemia. Hematol Oncol 2013;31(2):103-109.

[54] Sprycel (dasatinib) tablets, summary of products characteristics. September 2012.

[55] Lewandowski K, Sacha T, Żołnierowicz J, et al. Zarządzanie objawami niepożądanymi inhibitorów kinaz tyrozynowych u chorych na przewlekłą białaczkę szpikową. W: Warzocha $\mathrm{K}$, red. Biblioteka czasopisma Hematologia. Via Medica, Gdańsk: Przewlekła białaczka szpikowa; 2013. p. 71-87.

[56] O’Brien S, Deininger M, Pinilla-Ibarz J, et al. NCCN Clinical Practice Guidelines in Oncology (NCCN Guidelines) Chronic Myelogenous Leukemia. Version 3.2014 [online]. Protokół dostępu: http://www.nccn.org/professionals/physician_gls/ pdf/cml.pdf.[2014,June, 30].

[57] Montani D, Bergot E, Günter S, et al. Pulmonary arterial hypertension in patients treated by dasatinib. Circulation 2012;125:2128-2137. 
[58] Peng B, Lloyd P, Schran H. Clinical pharmacokinetics of imatinib. Clin Pharmacokinet 2005;44(9):879-894.

[59] Brendel C, Scharenberg C, Dohse M, et al. Imatinibmesylate and nilotinib (AMN107) exhibit high-affinity interaction with ABCG2 on primitive hematopoietic stem cells. Leukemia 2007;21(6):1267-1275.

[60] Ozvegy-Laczka C, Hegedus T, Varady G, et al. High-affinity interaction of tyrosine kinase inhibitors with the ABCG2 multidrug transporter. Mol Pharmacol 2004;65(6):1485-1495.

[61] Cancercare.on.ca [homepage]. Toronto: Cancer, Care Ontario. 2010 [updated 2010; cited 2010]., http://www. cancercare.on.ca/. Accessed August 19, 2010.

[62] UpToDate.com 2010 [homepage] Waltham: UpToDate [updated 2010; cited 2010]. http://www.uptodate.com/. Accessed August 19, 2010.

[63] Lagas JS, van Waterschoot RA, van Tilburg VA, et al. Brain accumulation of dasatinib is restricted by P-glycoprotein (ABCB1) and breast cancer resistance protein (ABCG2) and can be enhanced by elacridar treatment. Clin Cancer Res 2009;15(7):2344-2351.

[64] Haouala A, Widmer N, Duchosal MA, et al. Drug interactions with the tyrosine kinase inhibitors imatinib, dasatinib, and nilotinib. Blood 2011;117:e75-e87.

[65] White DL, Saunders VA, Dang P, et al. OCT-1- mediated influx is a key determinant of the intracellular uptake of imatinib but not nilotinib (AMN107): reduced OCT-1 activity is the cause of low in vitro sensitivity to imatinib. Blood 2006;108(2):697-704.
[66] Tripplitt C. Drug Interactions of Medications Commonly Used in Diabetes. Diabetes Spectrum 2006 Oct;19(4):202-211.

[67] Mastan SK, Chaitanya G, Reddy KR, et al. An appraisal to the special sulphonylurea: gliclazide. Pharmacologyonline 2009;1:254-269.

[68] Satyanarayana S, Eswar Kumar K, Rajasekhar J, et al. Influence of aqueous extract of fenugreek-seed powder on the pharmacodynamics and harmacokinetics of gliclazide in rats and rabbits. Therapy 2007;4:457-463.

[69] He YL. Clinical pharmacokinetics and pharmacodynamics of vildagliptin. Clin Pharmacokinet 2012;51(3):147-162.

[70] Obermeier M, Yao M, Khanna A, et al. In vitro characterization and pharmacokinetics of dapagliflozin (BMS-512148), a potent sodium-glucose cotransporter type II inhibitor, in animals and humans. Drug Metab Dispos 2010;38(3):405-414.

[71] Invokana - summary of product characteristics: http:// www.ema.europa.eu/docs/en_GB/document_library/ EPAR_-_Product_Information/human/002649/ WC500156456.pdf.

[72] Deininger M, O'Brien S, Guilhot F, et al. International Randomized Study of Interferon Vs STI571 (IRIS) 8-Year Follow up: Sustained Survival and Low Risk for Progression or Events in Patients with Newly Diagnosed Chronic Myeloid Leukemia in Chronic Phase (CML-CP) Treated with Imatinib. ASH 2009. Abst 1126. 